\title{
INVESTIGATION OF THE STATIC ICING PROPERTY FOR SUPER-HYDROPHOBIC COATINGS ON ALUMINIUM
}

\author{
PREISKAVA LASTNOSTI STATIČNE ZALEDENITVE PRI \\ SUPERHIDROFOBNIH PREVLEKAH NA ALUMINIJU
}

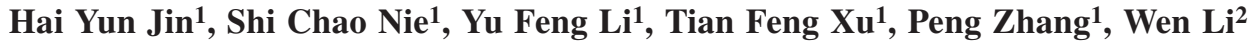 \\ ${ }^{1}$ Xi' an Jiaotong University Xi'an, State Key Laboratory of Electrical Insulation and Power Equipment, 710049, China \\ ${ }^{2}$ Hubei Polytechnic University, Hubei Key Laboratory of Mine Environmental Pollution Control \& Remediation and School of Chemical and \\ Materials Engineering, Huangshi, 435003, China \\ 1xfzzl@126.com \\ Prejem rokopisa - received: 2016-09-02; sprejem za objavo - accepted for publication: 2016-10-24
}

\begin{abstract}
An anti-icing aluminium with a super-hydrophobic surface was fabricated. A static icing system was developed to investigate the process of static icing for samples with different contact angles (CAs), and the contact state was also researched. The results showed that the water droplets' solidification time on a super-hydrophobic surface was much longer than for other surfaces at the same temperature. A water droplet on the super-hydrophobic surface had a much smaller contact area than on another surfaces. In addition, the air gap between the droplet and the super-hydrophobic surface retarded and prevented any exchange of heat. The temperature affected the transition from the Cassie state to the Wenzel state for super-hydrophobic aluminium.

Keywords: aluminium coating, static icing, solidification time, super hydrophobicity
\end{abstract}

Narejeno je bilo preprečevanje zaledenitve aluminija s superhidrofobno plastjo. Sistem statične zaledenitve je bil razvit za preiskavo procesa statične zaledenitve za vzorce z različnimi kontaktnimi koti (angl. CA), preiskano pa je bilo tudi stanje kontakta. Rezultati so pokazali, da je čas strjevanja vodnih kapljic na superhidrofobni površini precej daljši kot na drugih površinah pri enaki temperaturi. Vodna kapljica je imela na superhidrofobni površini precej manjšo kontaktno površino kot na drugih površinah. Poleg tega je zračna reža med kapljicami in superhidrofobno površino zaustavljala in preprečevala vsako izmenjavo toplote. Temperatura je vplivala na prehod iz stanja Cassie v stanje Wenzel za superhidrofobni aluminij.

Ključne besede: aluminijeva prevleka, statična zaledenitev, čas strjevanja, superhidrofobnost

\section{INTRODUCTION}

Icing is a natural phenomenon that occurs on the surfaces of objects in the bad conditions of low temperatures and freezing rain. An ice disaster is a serious natural disaster for a power system,,$^{1,2}$ especially for abnormal weather with the El Nino and La Nina phenomena, the ice disaster became more frequently. In the past, for a long time, de-icing methods were active, and external energy was required to deal with the icing on the surfaces. ${ }^{3,4}$ In recent years, anti-icing coatings that could improve the icing performance effectively received more attention, such as electric heating coatings, photo-thermal coatings and hydrophobic coatings. Two features are required for promising anti-icing materials. One is that overcooled water droplets can roll off from the surface easily before crystallization. And the other, is that the ice adhesion will be weaker when the ice is accumulated on the surface. ${ }^{5}$ Super-hydrophobic coatings are promising materials due to the retardation and prevention of icing and have become a focus of study. ${ }^{6-16}$

The researches on super-hydrophobic materials for anti-icing are abundant; however, there are few reports about the process in detail of water condensing and then freezing to form ice on a cold super-hydrophobic surface. ${ }^{14,15} \mathrm{M}$. He et al. ${ }^{14}$ fabricated super-hydrophobic surfaces with isotactic polypropylene; the results showed that the micro- and nanometre structures led to a delay of the solidification of liquid water at the three phase line region. M. He et al. ${ }^{14}$ fabricated super-hydrophobic surfaces with $\mathrm{ZnO}$ nanorod arrays; the process of icing at different temperatures below the freezing point was studied. ${ }^{15}$ However, the effect on the mechanism is unclear and needs more systemic and deep research. Furthermore, there are few reports about super-hydrophobic aluminium used in a power transmission line. Aluminium has good thermal conductivity, so different phenomenon may occur in the process of icing. S. L. Zheng et al. ${ }^{17,18}$ fabricated super-hydrophobic aluminium coatings using the Electrochemical Corrosion Method. The adhesion strength of ice on coatings was researched, but the process of solidification of the droplets was not mentioned.

In this paper, super-hydrophobic coatings were fabricated using the Chemical Etching Method and a static icing system was developed to study the ice crystallization process of super-cooled water droplets on different coatings and different temperatures below the freezing point. The results are helpful to provide theoretical basis effectively for the design and fabrication of super-hydrophobic transmission aluminium conductors in the future. 
H. Y. JIN et al.: INVESTIGATION OF THE STATIC ICING PROPERTY FOR SUPER-HYDROPHOBIC COATINGS ...

\section{EXPERIMENTAL PART}

In order to fabricate samples with different hydrophobicities, a pre-treatment was necessary for the electrically pure aluminium. First, 1000 mesh sandpaper was used to polish the surface of the aluminium for the purpose of removing dense oxide layer, then using water and absolute ethyl alcohol to clean filth and grease on the surface by ultrasonic cleaning for $10 \mathrm{~min}$. After pre-treatment, the aluminium can be used as a hydrophilic aluminium surface samples (A1). Using stearic acid to modify the aluminium surface, stearic acid is a kind of long-chain fatty acid and has a lower free energy. As shown in Figure 1, a dehydration reaction would happen between hydroxyl groups on the surface of the aluminium and the carboxyl group in stearic acid. Then a tight and thin coating with low free energy would be generated on the surface of the aluminium and hydrophobic aluminium surface samples (A2) could be obtained. As for super-hydrophobic aluminium surface samples, put the aluminium after pre-treatment to the $20 \%$ of mass fractions of hydrochloric acid to etch for 1 min, after drying put it in the $1 \%$ of mass fractions of stearic acid to modify the surface energy for $15 \mathrm{~min}$, finally put the sample into the $90{ }^{\circ} \mathrm{C}$ oven to fabricate super-hydrophobic aluminium surface samples (A3). ${ }^{19}$

Figure 2 shows that static icing system was made up of a Peltier chip, the cooling fan, temperature sensors and a temperature controller. The Peltier chip (TEC-1206) was supplied with power by a $12 \mathrm{~V}$ DC powervsupply, the temperature difference between cold end and hot end was $75^{\circ} \mathrm{C}$ and the temperature on the cold end could be $-20{ }^{\circ} \mathrm{C}$. The microprocessor in the semiconductor refrigeration temperature controller (TTC-B) was used to control the DC power in order to realize the temperature control. The test of static icing characteristics was completed at room temperature. In order to compare the process of icing, three kinds of typical aluminium wire samples (A1, A2 and A3) were observed. Detailed test steps was as follows:

1) Setting the surrounding environment in a darkroom, the entire Peltier cooling system was placed in a simple studio, the illumination was backlit bright LED projection mode, and the Peltier chip temperature was kept constant by adjusting the parameters of the PID
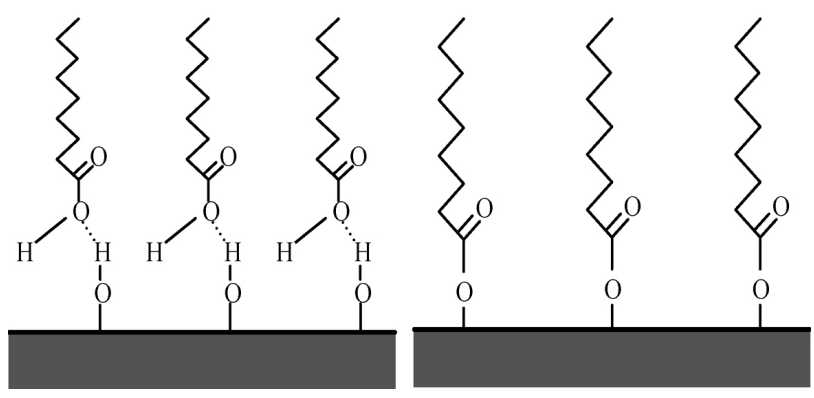

Figure 1: Modification mechanism of stearic acid on the aluminium surface

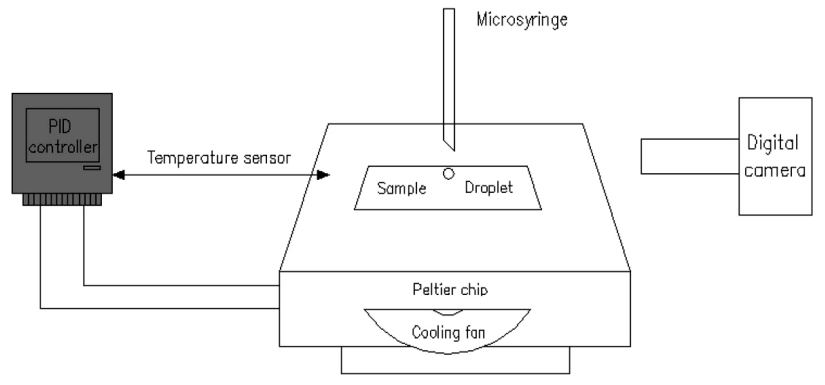

Figure 2: Schematic diagram of static icing test system

control system $\left(-5{ }^{\circ} \mathrm{C} \pm 0.5{ }^{\circ} \mathrm{C},-3{ }^{\circ} \mathrm{C} \pm 0.5{ }^{\circ} \mathrm{C}\right.$ and $-1{ }^{\circ} \mathrm{C}$ $\pm 0.5{ }^{\circ} \mathrm{C}$ ), and recorded both the ambient temperature and the humidity value;

2) Turning on the power of the Peltier cooling system. When the temperature of the surface was constant, we placed the samples on the Peltier surface, $15 \mu \mathrm{L}$ water droplets were injected onto the samples' surface rapidly by using a micro-syringe, and we recorded the solidification process of droplets using a digital camera.

\section{RESULTS AND DISCUSSION}

Figure 3 shows the CA of droplets on 3 typical aluminium samples at room temperature. The CA on A1, A2 and A3 were $82^{\circ}, 109^{\circ}$ and $152^{\circ}$, respectively. Heat transfer happened between the droplets and the cold surface. Droplets placed on the surface of sample were liquid at first, and because of the results of differences of hydrophobicity, different contact states on three different surfaces were observed. As shown in Figure 3, the droplet on the surface of A1 was like a pan upside down, it had largest contact area; the droplet on the surface of A2 was like a semicircle, it had larger contact area and droplet on the surface of A3 was like a ball, it had the smallest contact area.

Figure 4 shows SEM images and 3D laser scanning of $\mathrm{A} 3$, it can be seen that A3 had many micron structure pits and protrusions, and the size of these pits and protrusions was about $3 \mu \mathrm{m}$. From Figure $\mathbf{4 b}$ and $\mathbf{4 d}$, a rough structure similar with building blocks could be observed, so the pits and protrusions connected with each other. Besides, the micron pits and protrusions had submicron even nano-sized rough structure on their surfaces. This surface structure was easy to form super hydrophobicity with a water droplet. ${ }^{20}$

Figure 5 showed droplets' solidification process on samples (surface temperature is $-3{ }^{\circ} \mathrm{C}$ ). Droplets on the surface of samples were liquid at first, as the time pro-

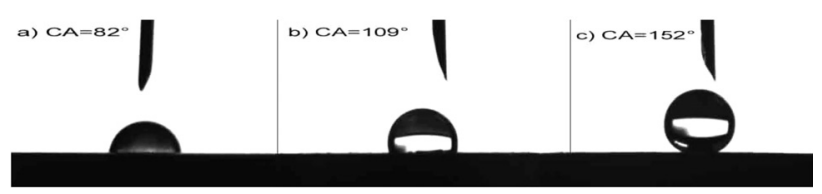

Figure 3: Contact angle of droplets on 3 typical aluminium samples at room temperature: a) A1, b) A2 and c) A3 
H. Y. JIN et al.: INVESTIGATION OF THE STATIC ICING PROPERTY FOR SUPER-HYDROPHOBIC COATINGS ...
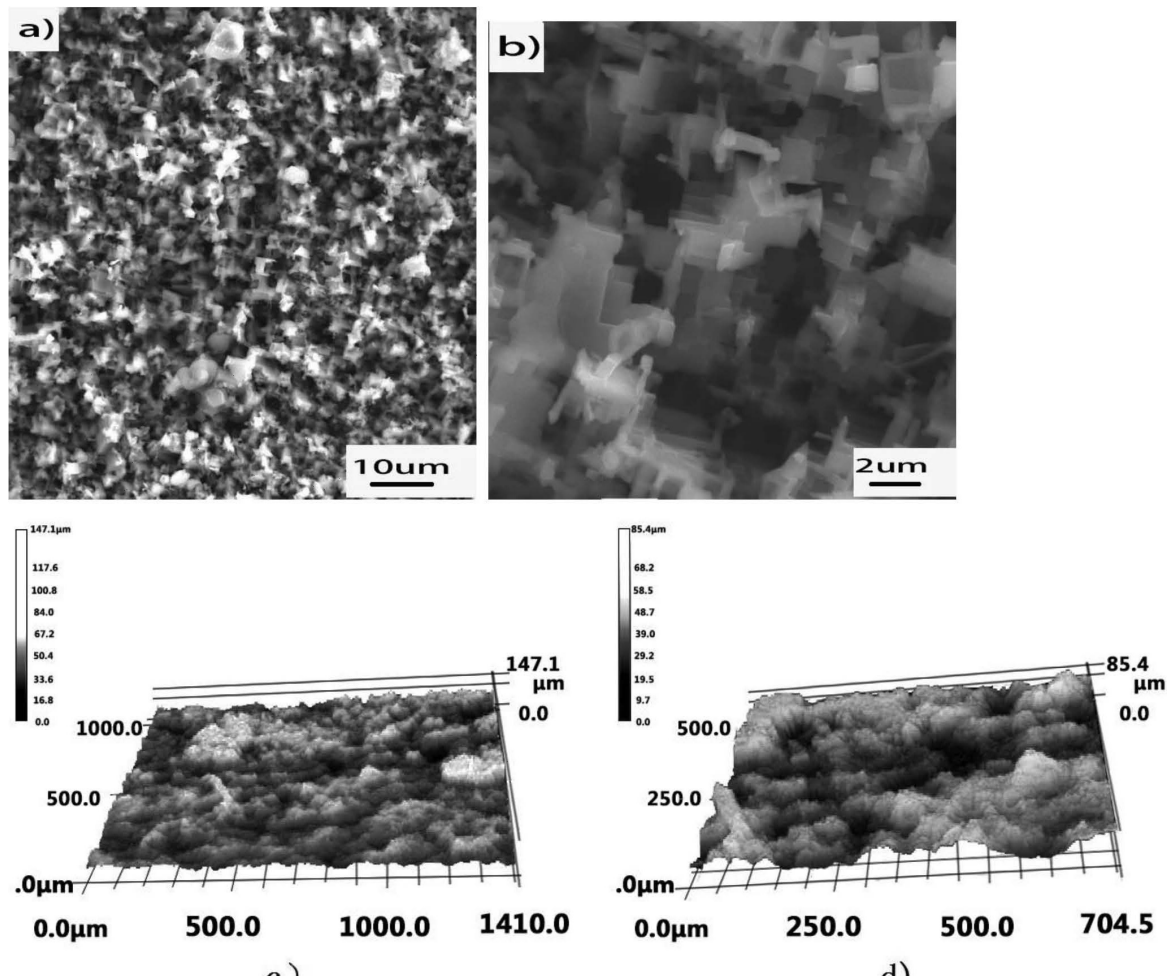

c)

d)

Figure 4: Microstructure of A3: a) The SEM image magnified 1000 times, b) the SEM image magnified 5000 times, c) the 3D laser scanning magnified 10 times and d) the 3D laser scanning magnified 20 times

longed, gas/liquid/solid three phase contact line between droplet and surface of sample expanded, and the contact area between the droplet and the surface increased, which meant the CA decreasing as the time prolonged. A phase transition occurred in the droplets because of the heat transfer between the cold surfaces and the droplets, which meant the transition from liquid to solid for the droplets. Also shown was the process of solidification after the phase transition, a clear liquid/solid line could be observed and this line grew up from bottom to the top. Under the liquid/solid line, the droplets were already frozen ice. Above the line, the droplets were still liquid. The liquid/solid line grew up at different speeds on three typical aluminium surfaces; the line grew up quickly on the A1 and A2 but relatively slowly on the A3. The line went up to the top of the droplet, and finally, a peak on the top of droplet was generated, which meant the end of solidification process.

Figure 5 showed the phase transition time on different surfaces. The phase transition starting times for A1, A2 and A3 were 20 s, 34 s and 348 s, respectively. The phase-transition time on A3 was much longer than the other two surfaces. The solidification time for total droplet for A1, A2 and A3 were $38 \mathrm{~s}, 49 \mathrm{~s}$ and $404 \mathrm{~s}$, respectively, the solidification time increased with increasing CA. The solidification time of the droplet for A3 was 10.6 times that of for A1 and 8.2 times that of for A2. Therefore, the solidification process of water

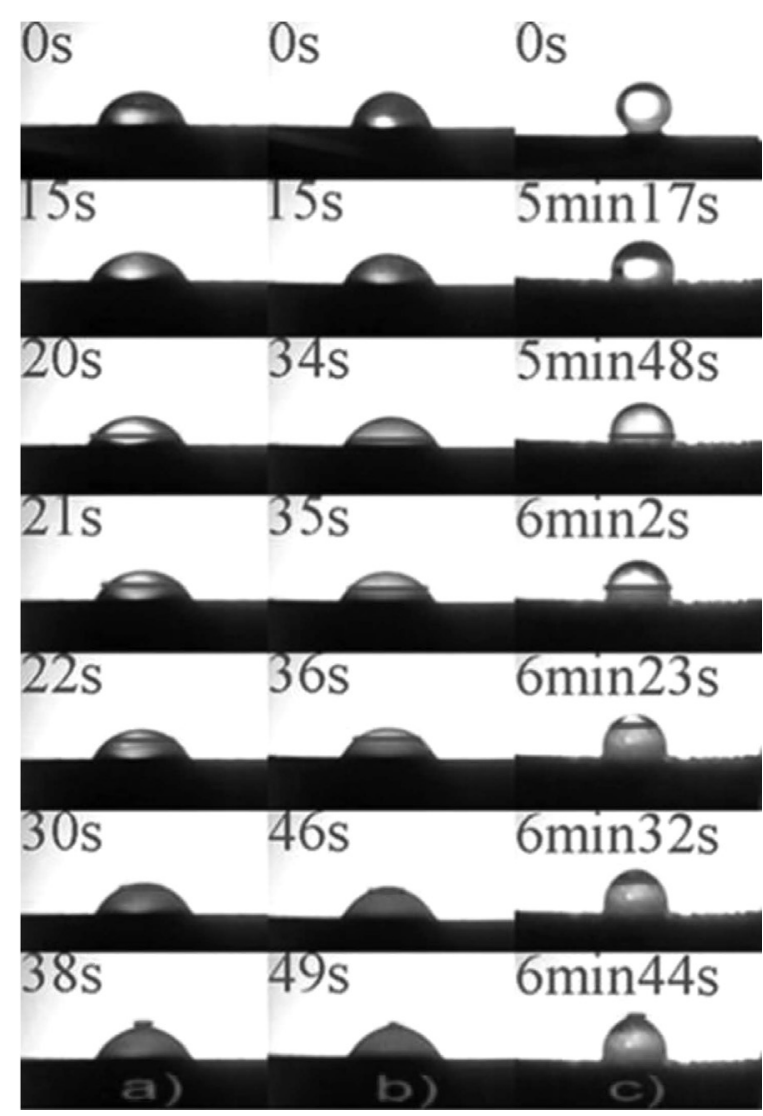

Figure 5: Droplets' solidification process on the surfaces of 3 typical aluminum wire samples, the red lines are the boundary of liquid and solid: a) A1, b) A2 and c) A3 
droplet could be greatly delayed by the super-hydrophobic surface (A3).

The results show that the $\mathrm{CA}$ directly affects the freezing process of the droplets. For A1 and A2, the contact states between droplets and surfaces were the Wenzel state. The contact angle on A2 was larger than on $\mathrm{A} 1$, so the contact area between the droplet and A2 was smaller. For A3, the contact state of ball-like droplet made the smallest contact area. It was known that the heat-transfer rate was related to the contact area ${ }^{21}$, solidification time on A3 was the longest. At the same time, the vertical height of the droplet on A3 was greater, which meant more distance and time should be required for the solidification process from the bottom to the top of the droplet, therefore, the solidification time on A3 was the longest. On the other hand, for A3, the contact state was the Cassie state. There were a lot of air films in the contact interface and the air films played a role of energy barrier, which greatly delayed the heat exchange process between the droplets and surfaces, so the solidification time of droplets for A3 surface was also much longer than the other two surfaces.

After solidification, the top of the droplet would form a peak, and there were two main reasons for this: one was that the volume of droplets increased from liquid to solid; the other was that the droplet contained some of air, the dissolved air would form bubbles and released out of droplet during the process of phase transition and solidification. However, the peak of the droplet on the super-hydrophobic surface was more acute, which indicated that there was other air in the droplet besides the dissolved air, the explanation for this phenomenon could be the involvement of an air film between the droplet and the surface of the super-hydrophobic aluminium sample. Results might indirectly prove that the contact state of the droplet and the super-hydrophobic aluminium surface was in the Cassie contact state.

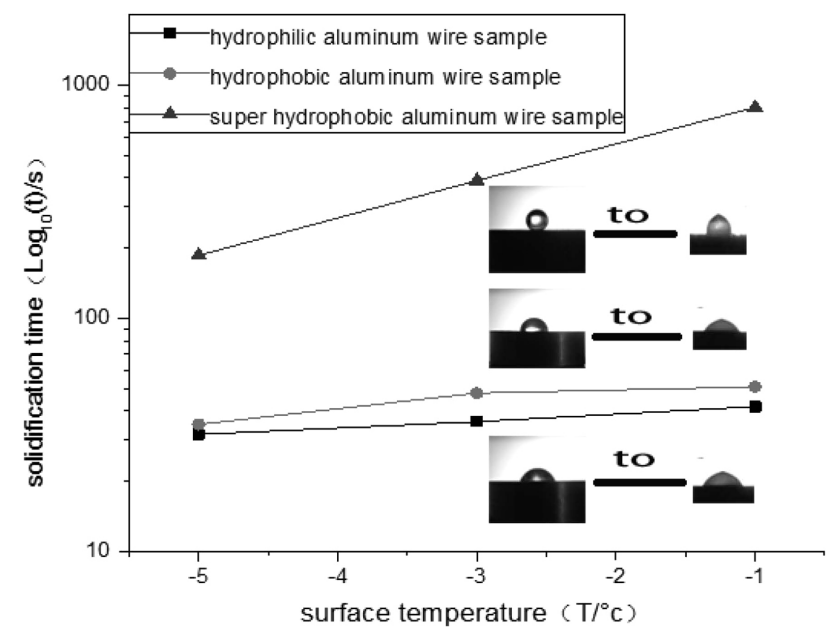

Figure 6: Relationship between solidification time and surface temperature: the picture shows the initial liquid state and the final solid state of the water droplets on $\mathrm{A} 3$ when the surface temperature is $-3{ }^{\circ} \mathrm{C}$
Figure 6 shows the relationship between the solidification time and surface temperature (the data of solidification time was average data of five experiments). When the surface temperature was $-1{ }^{\circ} \mathrm{C}$, the solidification times for A1, A2 and A3 were $41.7 \mathrm{~s}, 50.7 \mathrm{~s}$ and $803.7 \mathrm{~s}$, respectively. When the surface temperature of the samples was $-3{ }^{\circ} \mathrm{C}$, the solidification time for A1, A2 and $\mathrm{A} 3$ were $36 \mathrm{~s}, 47.7 \mathrm{~s}$ and $390 \mathrm{~s}$ respectively. When the surface temperature was $-5^{\circ} \mathrm{C}$, the data were $31.7 \mathrm{~s}$, $35 \mathrm{~s}$ and $186 \mathrm{~s}$, respectively. From Figure 6 it can be seen that with the reduction of surface temperature, the solidification time of the droplets on three typical samples should decrease. This was because of the increase of the energy exchange speed and the decrease of nucleation barrier of surfaces with decreasing surface temperature. At different surface temperatures the solidification time of the droplets on A3 was much longer than A1 and A2, which showed the excellent static anti-icing performance of $\mathrm{A} 3$. When the surface temperatures were $-1{ }^{\circ} \mathrm{C},-3{ }^{\circ} \mathrm{C}$ and $-5{ }^{\circ} \mathrm{C}$, the droplets' solidification times on A3 were $803.7 \mathrm{~s}, 390.0 \mathrm{~s}$ and $186.0 \mathrm{~s}$, respectively. With a decreasing surface temperature, the solidification time of the droplets on A3 fell more rapidly than the other two typical surfaces. Due to the instability of the air film between the droplets and surface, ${ }^{22}$ the contact state change from the Cassie state to the Wenzel state could become easier for A3, with temperature decreasing (Figure 5c) for $0 \mathrm{~s}$ and $5 \mathrm{~min} 17 \mathrm{~s}$.

\section{CONCLUSIONS}

In summary, the super-hydrophobic coatings on aluminium $\left(\mathrm{CA}=152^{\circ}\right)$ were fabricated by Chemical Etching and Modification Method. For the super-hydrophobic surface, the solidification and phase-change time of the droplets were much longer than the hydrophilic aluminium surface and the hydrophobic aluminium surface. This was because for the super-hydrophobic aluminium surfaces the freezing process could be retarded and prevented by both smaller contact area and air film between droplet and surface (Cassie contact state), which influenced the thermal exchange between the droplet and the surface.

Due to that the air film latched by the droplet on the super-hydrophobic surface was not stable, with the temperature decreasing, the droplet transited from the Cassie contact state to the Wenzel contact state more easily.

\section{Acknowledgements}

This research was financially supported by the National Natural Science Foundation of China (No. 51272208), the Natural Science Foundation of Hubei Province (2010CDA026), the Key Program of Hubei Provincial Department of Education (Z20104401), the Outstanding Scientific and Technological Innovation 


\section{MATERIALI IN TEHNOLOGIJE/MATERIALS AND TECHNOLOGY (1967-2017) - 50 LET/50 YEARS}

\section{H. Y. JIN et al.: INVESTIGATION OF THE STATIC ICING PROPERTY FOR SUPER-HYDROPHOBIC COATINGS ...}

Team Project of Universities in Hubei Province (T201423), and the Talent Program of Hubei Polytechnic University (11yjz04R).

\section{REFERENCES}

${ }^{1}$ Y. Hu, Analysis and Countermeasures Discussion for Large Area Icing Accident on Power Grid, High Voltage Engineering, 34 (2008) 2, 215-219, doi:10.13336/j.1003-6520.hve.2008.02.020

${ }^{2}$ Y. Yang, J. Li, J. Hu, Y. Zhao, X. Jiang, C. Sun, Experimental Study on Icing Properties of Superhydrophobic Coatings on Insulators, High Voltage Engineering, 36 (2010) 3, 621-626, doi:10.13336/ j.1003-6520.hve.2010.03.013

${ }^{3}$ J. Laforte, M. Allaire, J. Laflamme, State-of-the-art on power line de-icing, Atmospheric Research, 46 (1998) 1, 143-158, doi:10.1016/ S0169-8095(97)00057-4

${ }^{4}$ O. Parent, A. Ilinca, Anti-icing and de-icing techniques for wind turbines: Critical review, Cold Regions Science and Technology, 65 (2011) 1, 88-96, doi:10.1016/j.coldregions.2010.01.005

${ }^{5}$ Y. Wang, J. Xue, Q. Wang, Q. Chen, J. Ding, Verification of Icephobic/Anti-icing Properties of a Superhydrophobic Surface, ACS applied materials \& interfaces, 5 (2013) 8, 3370-3381, doi:10.1021/am400429q

${ }^{6}$ G. Fang, A. Amirfazli, Understanding the anti-icing behavior of superhydrophobic surfaces, Surface Innovations, 2 (2014) 2, 94-102, doi:10.1680/si.13.00046

${ }^{7}$ S. Farhadi, M. Farzaneh, S. Kulinich. Anti-icing performance of superhydrophobic surfaces, Applied Surface Science, 257 (2011) 14, 6264-6269, doi:10.1016/j.apsusc.2011.02.057

${ }^{8}$ T. Kako, A. Nakajima, H. Irie, Z. Kato, K. Uematsu, T. Watanabe, K. Hashimoto, Adhesion and sliding of wet snow on a super-hydrophobic surface with hydrophilic channels, Journal of Materials Science, 39 (2004) 2, 547-555, doi:10.1023/B:JMSC.0000011510. 92644.3f

${ }^{9}$ Y. Tang, Q. Zhang, X. Zhan, F. Chen, Superhydrophobic and anti-icing properties under overcooled temperature of fluorinated hybrid surface prepared via sol-gel process, Soft Matter, 11 (2015) 22, 4540-4550, doi:10.1039/c5sm00674k

${ }^{10}$ P. Tourkine, M. Le Merrer, D. Quéré, Delayed freezing on water repellent materials, Langmuir, 25 (2009) 13, 7214-7216, doi:10.1021/la900929u

${ }^{11}$ T. Bharathidasan, S.V. Kumar, M. Bobji, R. Chakradhar, B. J. Basu, Effect of wettability and surface roughness on ice-adhesion strength of hydrophilic,hydrophobic and superhydrophobic surfaces, Applied Surface Science, 314 (2014), 241-250, doi:10.1016/j.apsusc.2014. 06.101
${ }^{12}$ S. Kulinich, M. Farzaneh, How wetting hysteresis influences ice adhesion strength on superhydrophobic surfaces, Langmuir, 25 (2009) 16, 8854-8856, doi:10.1021/la901439c

${ }^{13} \mathrm{~S}$. Kulinich, M. Farzaneh, Ice adhesion on super-hydrophobic surfaces, Applied Surface Science, 255 (2009) 18, 8153-8157, doi:10.1016/j.apsusc.2009.05.033

${ }^{14}$ M. He, J. X. Wang, H. L. Li, X. L. Jin, J. J. Wang, B. Q. Liu, Y. L. Song, Super-hydrophobic film retards frost formation, Soft Matter, 6 (2010) 11, 2396-2399, doi:10.1039/c0sm00024h

${ }^{15}$ M. He, J. Wang, H. Li, Y. Song, Super-hydrophobic surfaces to condensed micro-droplets at temperatures below the freezing point retard ice/frost formation, Soft Matter, 7 (2011) 8, 3993-4000, doi:10.1039/c0sm01504k

${ }^{16}$ J. Durret, N. Frolet, C. Gourgon. Hydrophobicity and anti-icing performances of nanoimprinted and roughened fluoropolymers films under overcooled temperature, Microelectronic Engineering, 155 (2016), 1-6, doi:10.1016/j.mee.2016.01.011

${ }^{17}$ S. Zheng, C. Li, Q. Fu, M. Li, W. Hu, Q. Wang, M. Du, X. Liu, Z. Chen, Fabrication of self-cleaning superhydrophobic surface on aluminum alloys with excellent corrosion resistance, Surface \& Coatings Technology, 276 (2015), 341-348, doi:10.1016/j.surfcoat. 2015.07.002

${ }^{18}$ S. Zheng, C. Li, Q. Fu, W. Hu, T. Xiang, Q. Wang, M. Du, X. Liu, Z. Chen, Development of stable superhydrophobic coatings on aluminum surface for corrosion-resistant, self-cleaning, and anti-icing applications, Materials and Design, 93 (2016), 261-270, doi:10.1016/j.matdes.2015.12.155

${ }^{19}$ Z. Huang, Y. Li, P. Jin, M. Hu, B. He, N. Gao, H. Zhang, H. Jin, Fabrication of Aluminum Superhydrophobic Surface with Facile Chemical Etching Method, Materials Science Forum, 804 (2015), 103-106, doi:10.4028/www.scientific.net/MSF.804.103

${ }^{20}$ L. Jiang, Nanostructured Materials with Super-hydrophobic Surface-from Nature to Biomimesis, Chemical Industry and Engineering Progress, 22 (2003) 12, 1258-1264, doi:10.3321/j.issn:1000-6613. 2003.12.002

${ }^{21}$ O. R. Enriquez, A.G. Marin, K. G. Winkels, J. H. Snoeijer, Freezing singularities in water drops, Physics of Fluids, 24 (2012) 9, 091102, doi:10.1063/1.4747185

${ }^{22}$ H. Y. Jin, Y. F. Li, P. Zhang, S. C. Nie, N. K. Gao, The investigation of the wetting behavior on the red rose petal, Applied physics Letter, 108 (2016) 15, 151605, doi:10.1063/1.4947057 